\title{
Dietary moderately oxidized oil induces expression of fibroblast growth factor 21 in the liver of pigs
}

Juliane Varady, Robert Ringseis ${ }^{*}$ and Klaus Eder

\begin{abstract}
Background: Fibroblast growth factor 21 (FGF21), whose expression is induced by peroxisome proliferatoractivated receptor $\alpha$ (PPAR $\alpha$ ), has been recently identified as a novel metabolic regulator which plays a crucial role in glucose homeostasis, lipid metabolism, insulin sensitivity and obesity. Previous studies have shown that administration of oxidized fats leads to an activation of PPAR $\alpha$ in the liver. Therefore, the present study investigated the hypothesis that feeding of oxidized fats causes an induction of FGF21 in the liver.

Methods: Twenty four crossbred pigs were allocated to two groups of 12 pigs each and fed nutritionally adequate diets with either fresh rapeseed oil or oxidized rapeseed oil prepared by heating at a temperature of $175^{\circ} \mathrm{C}$ for 72 h.

Results: In pigs fed the oxidized fat mRNA abundance and protein concentrations of FGF21 in liver were significantly increased $(P<0.05)$, and the protein concentrations of FGF21 in plasma tended to be increased $(P<$ 0.1) in comparison to control pigs. Moreover, pigs fed the oxidized fat had increased transcript levels of the PPAR $\alpha$ target genes acyl-CoA oxidase, carnitine palmitoyltransferase-1 and novel organic cation transporter 2 in the liver $(P$ $<0.05)$, indicative of PPAR $\alpha$ activation.

Conclusion: The present study shows for the first time that administration of an oxidized fat induces the expression of FGF21 in the liver, probably mediated by activation of PPAR $\alpha$. Induction of FGF21 could be involved in several effects observed in animals administered an oxidized fat.
\end{abstract}

Keywords: Fibroblast growth factor 21, Liver, Peroxisome proliferator-activated receptor a, Pig, Oxidized fat

\section{Background}

Fibroblast growth factor 21 (FGF21) has been recently identified as a novel metabolic regulator which plays a crucial role in glucose homeostasis, lipid metabolism, insulin sensitivity and obesity [1-3]. The physiologic importance of FGF21 is evident from studies showing that systemic administration of FGF21 reduces serum and liver triacylglycerol (TAG) concentrations, body weight and obesity in obese mice [4-6]. Hepatic expression of FGF21 is strongly up-regulated during fasting and is rapidly suppressed by refeeding, indicating a role of FGF21 in fasting-induced response [1-3]. In the liver, FGF21 stimulates hepatic lipid oxidation, ketogenesis

\footnotetext{
* Correspondence: robert.ringseis@ernaehrung.uni-giessen.de

* Correspondence: robert.ringseis@ernaehrung.uni-giessen.de
Institute of Animal Nutrition and Nutrition Physiology, Justus-LiebigUniversity Giessen, Giessen, Germany
}

and gluconeogenesis [1]. Recently, it has been found that expression of FGF21 is induced by peroxisome proliferator-activated receptor $\alpha($ PPAR $\alpha)$, a transcription factor which is activated during fasting by non-esterified fatty acids released from adipose tissue or by administration of synthetic or natural PPAR $\alpha$ ligands such as fibrates or various types of fatty acids $[1,3,7,8]$.

Oxidized lipids as components of heated or fried foods play an important role in nutrition in industrialized countries [9]. The ingestion of oxidized fats is generally regarded as detrimental for health. However, some studies in rodents have shown that oxidized fats could also exert some beneficial effects on metabolism such as a reduction of plasma and liver TAG and cholesterol concentrations, a reduction of obesity and even an inhibition of atherosclerosis [10-16]. Moreover, it has been 
demonstrated that dietary oxidized fats can activate PPAR $\alpha$ in the liver [13,17-20].

Based on the finding that FGF21 is a target gene of PPAR $\alpha$, we tested the hypothesis that feeding an oxidized fat causes an induction of the expression of FGF21 in the liver which in turn raises the possibility that this hormonal factor is involved in several of the effects exerted by oxidized fats. For this end, we used samples from a recently performed experiment with pigs which received a moderately oxidized vegetable oil [21].

\section{Materials and methods \\ Animals and diets}

The samples used in this study were taken from animals of an experiment which has been recently reported in detail [21]. The experiment included 24 six week old pigs which were individually kept under adequate climate conditions. The pigs were allotted to two groups of 12 each. They were fed a nutritionally adequate diet which was composed of the following ingredients (in g/ kg diet): Wheat (181.9), barley (100), soybean meal (containing $44 \%$ crude protein, 350), wheat bran (146), oil (150), choline chloride (containing 50\% choline, 1.5), calcium hydrogen phosphate dehydrate [9], mineral and vitamin premix (40), L-lysine (containing 50.7 lysine, 16.5), DL-methionine (3.55), L-threonine (3.36), L-tryptophane (0.5). Concentrations of crude nutrients and vitamins and minerals were in accordance with recommendations for growing pigs [22]. The diets contained 16.4 MJ metabolizable energy, $224 \mathrm{~g}$ crude protein and $150 \mathrm{~g}$ of either a fresh or an oxidized oil per kg. As a source of oxidized oil, rapeseed oil which was heated in a domestic fryer at a temperature of $175^{\circ} \mathrm{C}$ for $72 \mathrm{~h}$ was used. As a source of fresh oil, a mixture of fresh rapeseed oil and fresh palm oil (91.6:8.4, w/w) was used. This fat mixture was used in order to equalize the fatty acid composition of the two oils (since the heating process caused a partial loss of PUFA in the rapeseed oil). Because the frying process caused a loss of tocopherols in the rapeseed oil, the vitamin $\mathrm{E}$ concentration of the oxidized fat was adjusted to that of the fresh fat by supplementation with all-rac- $\alpha$-tocopheryl acetate (the biopotency of all-rac- $\alpha$-tocopheryl acetate is considered to be $67 \%$ of that of $\alpha$-tocopherol). The vitamin E concentration in the fresh fat diet was $98 \mathrm{mg} \alpha$-tocopherol per $\mathrm{kg}$ diet, and that of the oxidized fat diet was adjusted accordingly. Concentrations of the major fatty acids and of some lipid peroxidation products in the fresh fat mixture and the oxidized fat are shown in Table 1.

In order to avoid potential differences in food intake, due to adverse sensoric properties of the oxidized fat, a controlled feeding system was applied in which pigs were offered the same amount of diet during the 29 days feeding period. Water was available ad libitum
Table 1 Fatty acid composition and concentrations of lipid peroxidation products in the experimental fats

\begin{tabular}{lcc}
\hline & Fresh fat & Oxidized fat \\
\hline Fatty acid composition (g fatty acid/100 $\mathbf{g}$ total fatty & acids) \\
16:0 & 9.3 & 6.8 \\
18:0 & 2.5 & 2.2 \\
18:1 & 55.4 & 60.5 \\
18:2 (n-6) & 21.9 & 21.1 \\
18:3 $(\mathrm{n}-3)$ & 7.0 & 5.4 \\
Lipid peroxidation products & & \\
Polar compounds (\%) & 2.82 & 23.1 \\
TBARS (mmol/kg) & 3.24 & 3.39 \\
Peroxides $\left(\mathrm{mEq} \mathrm{O}_{2} / \mathrm{kg}\right)$ & 0.63 & 7.39 \\
\hline
\end{tabular}

from nipple drinkers during the entire experiment. All experimental procedures described followed established guidelines for the care and handling of laboratory animals and were approved by the local Animal Care and Use Committee (Regierungspräsidium Giessen; permission no: GI 19/3 No. 49/2010).

\section{Sample collection}

After completion of the feeding period the animals were anaesthesised and exsanguinated $2.5 \mathrm{~h}$ after their last meal. Blood was collected into heparinized polyethylene tubes and plasma was subsequently obtained by centrifugation of the blood $\left(1100 \times \mathrm{g}, 10 \mathrm{~min}, 4^{\circ} \mathrm{C}\right)$. Tissue samples from liver were dissected and stored at $-80^{\circ} \mathrm{C}$ until analysis.

\section{Quantitative RT-PCR (qPCR)}

The mRNA expression levels in the liver were determined as described recently in detail [21,23]. Features of primer pairs of reference and target genes, reference gene-stability measure $M$ and data on qPCR performance for each gene measured in the liver are listed in Table 2.

\section{Determination of FGF21}

Concentrations of FGF21 in plasma and liver were quantified by an ELISA assay kit highly specific to porcine FGF21 (No. E92918Po, Uscn Life Science Inc., Wuhan, China) according to the manufacturer's instructions. For the measurement of FGF21 in liver, approximately $0.4 \mathrm{~g}$ of liver was homogenized in $3.6 \mathrm{~mL}$ of PBS (71.5 mM NaCl, $99.9 \mathrm{mM} \mathrm{Na} 2 \mathrm{HPO} 4 * 2 \mathrm{H}_{2} \mathrm{O}, 26.8 \mathrm{mM}$ $\mathrm{KCl}, 17.6 \mathrm{mM} \mathrm{KH}_{2} \mathrm{PO}_{4}$ ). Homogenates were centrifuged $\left(4.000 \times \mathrm{g}, 20 \mathrm{~min}, 4^{\circ} \mathrm{C}\right)$ and the supernatants were used for determination of FGF21 after dilution $(1+1$, vol/ vol) with PBS. Concentrations of FGF21 in liver homogenates were related to the protein concentrations in the homogenates as determined by the bicinchoninic acid (BCA) protein assay kit (Interchim, Montluçon, France) with BSA as standard. 
Table 2 Characteristics and performance data of the primers used for qPCR analysis and reference gene-stability measure $\boldsymbol{M}$

\begin{tabular}{|c|c|c|c|c|c|c|c|}
\hline Gene & $\begin{array}{l}\text { Forward primer (from } 5^{\prime} \text { to } 3^{\prime} \text { ) Reverse primer (from } \\
5^{\prime} \text { to } 3^{\prime} \text { ) }\end{array}$ & $\begin{array}{l}\text { PCR product size } \\
\text { (bp) }\end{array}$ & NCBI GenBank & Slope & $\mathrm{R}^{2}$ & Efficiency & $\begin{array}{c}M \\
\text { value }\end{array}$ \\
\hline \multicolumn{8}{|c|}{ Reference genes } \\
\hline ATP5G1 & $\begin{array}{l}\text { CAGTCACCTTGAGCCGGGCGA } \\
\text { TAGCGCCCCGGTGGTTTGC }\end{array}$ & 94 & NM_001025218.1 & -0.2661 & 0.9981 & 1.85 & 0.036 \\
\hline GPI & $\begin{array}{l}\text { CACGAGCACCGCTCTGACCT } \\
\text { CCACTCCGGACACGCTTGCA }\end{array}$ & 365 & NM_214330.1 & -0.2557 & 0.9964 & 1.80 & 0.034 \\
\hline RPS9 & $\begin{array}{l}\text { GTCGCAAGACTTATGTGACC } \\
\text { AGCTTAAAGACCTGGGTCTG }\end{array}$ & 327 & CAA23101 & -0.2705 & 0.9994 & 1.86 & 0.036 \\
\hline$\beta$-Actin & $\begin{array}{l}\text { GACATCCGCAAGCACCTCTA } \\
\text { ACATCTGCTGGAAGGTGGAC }\end{array}$ & 205 & NM_001167795 & -0.2637 & 0.9979 & 1.84 & 0.046 \\
\hline SDHA & $\begin{array}{l}\text { CTACGCCCCCGTCGCAAAGG } \\
\text { AGTTTGCCCCCAGGCGGTTG }\end{array}$ & 380 & DQ402993 & -0.2551 & 0.9986 & 1.80 & 0.041 \\
\hline \multicolumn{8}{|c|}{ Target genes } \\
\hline FGF21 & $\begin{array}{l}\text { CGATACCTCTACACGGATGA } \\
\text { CGTTGTAGCCATCCTCAAGT }\end{array}$ & 158 & NM_001163410.1 & -0.2773 & 0.9968 & 1.88 & - \\
\hline HMGCS2 & $\begin{array}{l}\text { ATGGAACGCACGCAGCTCCC } \\
\text { TCAGGCCCAACCAGCATGGC }\end{array}$ & 323 & NM_214380.1 & -0.2528 & 0.9983 & 1.79 & - \\
\hline $\mathrm{ACO}$ & $\begin{array}{l}\text { CTCGCAGACCCAGATGAAAT } \\
\text { TCCAAGCCTCGAAGATGAGT }\end{array}$ & 218 & AF185048 & -0.2495 & 0.9986 & 1.78 & - \\
\hline L-CPT1 & $\begin{array}{l}\text { GCATTTGTCCCATCTTTCGT } \\
\text { GCACTGGTCCTTCTGGGATA }\end{array}$ & 198 & AF288789 & -0.2654 & 0.9986 & 1.84 & - \\
\hline OCTN2 & $\begin{array}{l}\text { TGACCATATCAGTGGGCTA } \\
\text { AGTAGGGAGACAGGATGCT }\end{array}$ & 384 & XM_003123912 & -0.2517 & 0.998 & 1.79 & - \\
\hline
\end{tabular}

\section{Determination of 3-hydroxybutyrate}

Concentration of 3-hydroxybutyrate (3-HBA) in plasma was determined using an enzymatic reagent kit (Wako Chemicals GmbH, Neuss, Germany). In this assay, 3HBA in the sample is oxidized in the presence of 3 hydroxybutyrate dehydrogenase and thio-NAD. 3-HBA is assayed by measuring the rate of thio- $\mathrm{NADH}$ production spectrophotometrically at a wavelength of $405 \mathrm{~nm}$.

\section{Statistical analysis}

Treatment effects were analyzed with one-way ANOVA using the Minitab Statistical software Rel. 13.0 (Minitab, State college, PA, USA). Statistical significance of differences of the mean values of the two groups of pigs was evaluated using Student's t test. Means were considered tendentially different at $P<0.1$ and significantly different at $P<0.05$.

\section{Results}

\section{Concentrations of FGF21 in liver and plasma}

Pigs fed the oxidized fat had an increased relative mRNA abundance of FGF21 in the liver and an increased concentration of FGF21 in the liver compared to control pigs fed the fresh fat $(P<0.05$, Figure 1$)$. Plasma concentration of FGF21 in the pigs fed the oxidized fat was twice as much as in the pigs fed the fresh fat; however, the difference was not statistically significant due to a great standard deviation of the concentrations $(P<0.1$, Figure 1$)$.
Expression of PPAR $\alpha$ responsive genes in the liver Pigs fed the oxidized fat had increased relative mRNA abundance of various PPAR $\alpha$ responsive genes such as acyl-CoA oxidase (ACO), liver-type carnitine palmitoyltransferase 1 (L-CPT1) or novel organic cation transporter 2 (OCTN2) $(P<0.05$, Figure 2$)$, indicating an activation of hepatic PPAR $\alpha$ in these animals.
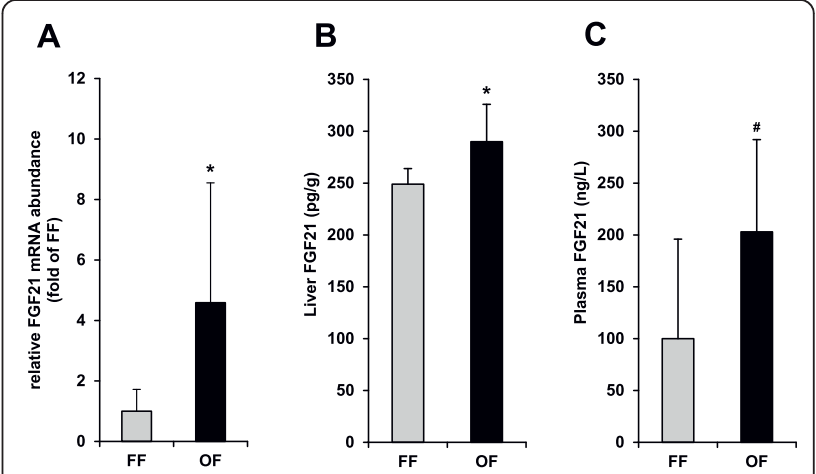

Figure 1 Relative mRNA abundance of FGF21 in the liver (A) and protein concentration of FGF21 in the liver (B) and plasma (C) of pigs fed either a fresh fat or an oxidized fat. Bars represent mean $\pm S D(n=12 /$ group), and are expressed as fold of fresh fat group. *Significantly $(P<0.05)$ and ${ }^{\# \text { in tendency }(P<0.1)}$ different from pigs fed the fresh fat. FF, fresh fat group; FGF21,

fibroblast growth factor 21; OF, oxidized fat group 


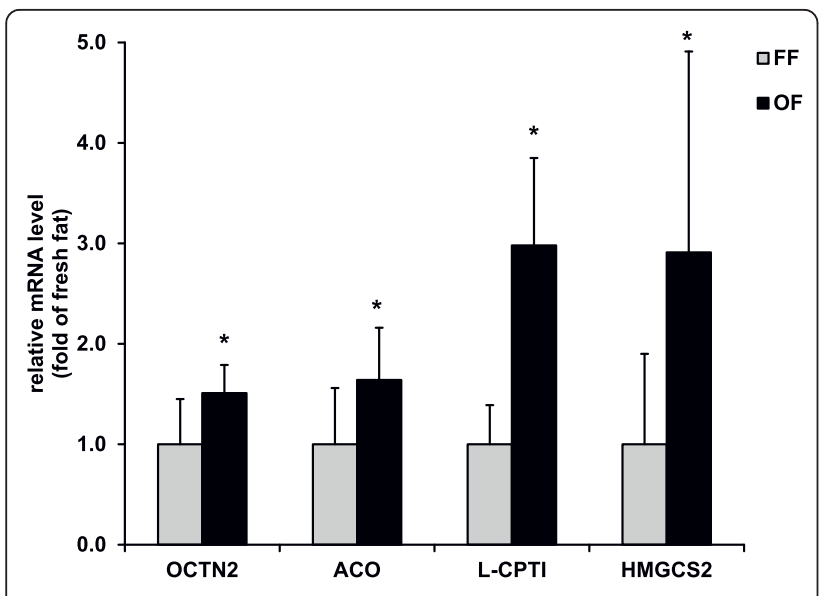

Figure 2 Relative mRNA abundance of OCTN2, ACO, L-CPT1 and HMGCS2 in the liver of pigs fed either a fresh fat or an oxidized fat. Bars represent mean $\pm S D(n=12$ /group), and are expressed as fold of relative mRNA abundance of the fresh fat group. *Different from pigs fed the fresh fat, $P<0.05$. ACO, acylCOA oxidase; HMGCS2, mitochondrial $\beta$-hydroxymethylglutaryl-CoA synthase 2; L-CPT1, liver-type carnitine palmitoyltransferase 1; FF, fresh fat group; OCTN2, novel organic cation transporter 2; OF, oxidized fat group

\section{Expression of hepatic mitochondrial $\beta$ -}

hydroxymethylglutaryl-CoA synthase 2 and plasma 3-HBA concentration

Pigs fed the oxidized fat had an increased relative mRNA abundance of mitochondrial $\beta$-hydroxymethylglutaryl-CoA synthase 2 (HMGCS2) in the liver $(P<$ 0.05 , Figure 2) and an increased concentration of 3 HBA in plasma compared to control pigs fed the fresh fat (fresh fat: $11.8 \pm 1.93 \mu \mathrm{mol} / \mathrm{L}$; oxidized fat: $17.3 \pm$ $7.35 \mu \mathrm{mol} / \mathrm{L} ; P<0.05)$.

\section{Discussion}

The aim of this study was to test the hypothesis that a dietary oxidized fat induces the expression of FGF21. For this end, we used samples of a recent experiment in which pigs were fed rapeseed oil heated in a domestic fryer under practical conditions [21]. Consideration of the concentrations of lipid peroxidation products (peroxides, TBARS, polar compounds) indicated that the oil used in that study was moderately oxidized and would be acceptable for frying of foods in human nutrition. The control fat and the oxidized fat were equalized for their fatty acid compositions and their vitamin E concentrations, and feed intake and body weight body gains of the pigs did not differ between the two groups [21]. Therefore, we can exclude the possibility that the effects observed in this study could have been confounded by a different intake of fatty acids or vitamin $\mathrm{E}$, or by a reduced growth rate. It is well known that over-night starvation leads to an activation of PPAR $\alpha$ which in turn induces the expression of FGF21 [2,3]. As we were interested in the effects of an oxidized fat on the expression of FGF21 without the distorting effect of fasting induced activation of PPAR $\alpha$, we collected the samples of the pigs in the fed state.

According to the hypothesis of this study, we observed for the first time that administration of an oxidized fat induced a strong induction of FGF21 in the liver, as indicated by a 5 -fold increase of the mRNA abundance of that hormone in the liver. Although there is no direct evidence for this, the induction of FGF21 in the liver was probably mediated by activation of PPAR $\alpha$. In order to assess activation of PPAR $\alpha$, we determined the expression of three known PPAR $\alpha$ target genes, namely ACO, L-CPT1 and OCTN2. The finding that these genes were up-regulated in the pigs fed the oxidized fat indicates an activation of PPAR $\alpha$ in these pigs. Activation of PPAR $\alpha$ in the liver induced by administration of oxidized fats has been established in rats and pigs $[13,17,19,24]$, although the effect in pigs in this regard is less pronounced than in rodents due to the fact that pigs have generally a lower expression of PPAR $\alpha$ and the response of many genes to PPAR $\alpha$ activation in pigs is much lower than in rodents $[25,26]$.

FGF21 has been recognized as a hormonal regulator that reduces plasma glucose and TAG concentrations, enhances insulin sensitivity, and inhibits development of obesity and hepatosteatosis [4-6]. Moreover, induction of FGF21 in the liver stimulates hepatic lipidnists, indicating that FGF21 and PPAR $\alpha$ have several overlapping effects. Indeed, there are several other metabolic effects induced by both, FGF21 and PPAR $\alpha$ agonists. For example, administration of both, PPAR $\alpha$ agonists such as fibrates and FGF21 lowered LDL-cholesterol, raised HDL-cholesterol, improved insulin sensitivity and prevented diet-induced obesity in rhesus monkeys and rodents [4,27-30]. Due to this striking overlap in activities, it has been suggested that FGF21 contributes to many of the actions of PPAR $\alpha$ agonists.

Studies in rodents have shown that many of the effects induced by administration of FGF21 such as a reduction of liver and plasma TAG concentrations $[10-12,18,19,31]$, a reduction of plasma cholesterol [10,13,31-33], an increase in HDL-cholesterol concentration [31], a reduction of adipose mass [15], or an increase of insulin sensitivity [34] are also induced by dietary oxidized fat. Previous studies have shown that dietary oxidized fats can even prevent an alcohol induced steatosis or the development of atherosclerosis $[16,35]$. In this study, we did not measure parameters of lipid or glucose metabolism. However, recent studies have also shown that administration of a moderately oxidized fat lowers plasma and LDL cholesterol concentrations and plasma TAG concentration [36,37] and 
increases plasma 3-HBA concentration in pigs [24]. These studies indicate that administration of an oxidized fat exerts also effects on lipid metabolism in pigs. Although concentrations of FGF21 in plasma and liver were less increased than FGF21 mRNA abundance by administration of the oxidized fat, it is likely that at least a part of the metabolic effects observed in animals fed an oxidized fat might be induced by FGF21. Up-regulation of HMGCS2, the key enzyme of ketogenesis, and an increased plasma concentration of 3-HBA observed in the pigs fed the oxidized fat in the present study, might also be - at least in part - induced by FGF21 which is regarded as key regulator of ketogenesis [2]. Given the similarities between pigs and humans with respect to expression of PPAR $\alpha$ [26] as an important regulator of FGF21 expression, the possibility exists that a dietary regime rich in fried foods containing oxidized fats induces hepatic expression of FGF21 in humans.

In conclusion, the present study shows for the first time that the ingestion of a moderately oxidized oil causes an induction of FGF21 in the liver of pigs, probably induced by activation of PPAR $\alpha$. This finding opens up the possibility that at least some of the effects observed in animals administered an oxidized fat are induced by FGF21.

\section{Abbreviations \\ ACO: Acyl-CoA oxidase; ATP5G1: ATP synthase, $\mathrm{H}+$ transporting: mitochondrial Fo complex, subunit C1; 3-HBA: 3-hydroxybutyrate; HMGCS2: Mitochondrial $\beta$-hydroxymethylglutaryl-CoA synthase 2; FF: Fresh fat group; FGF21: Fibroblast growth factor 21; GPI: Glucose-6-phosphate isomerase; L- CPT1: Liver isoform of carnitine palmitoyl transferase 1; OCTN2: Novel organic cation transporter 2; OF: Oxidized fat group; PPARa: Peroxisome proliferator-activated receptor a; RPS9: Ribosomal protein S9; SDHA: Succinate dehydrogenase complex, subunit A.}

\section{Acknowledgements}

This study was supported by a grant from the Deutsche

Forschungsgemeinschaft (DFG; grant no. Rl 1537/1-1).

\begin{abstract}
Authors' contributions
$\mathrm{J}$ carried out the experiments and participated in the interpretation of the data and drafted the manuscript. RR participated in the design of the study and supervised the experiment and analysis. KE conceived of the study and its design, coordinated work, participated in the interpretation of the results, and helped to draft the manuscript. All authors read and approved the final manuscript.
\end{abstract}

\section{Competing interests}

The authors declare that they have no competing interests.

Received: 4 February 2012 Accepted: 6 March 2012

Published: 6 March 2012

\section{References}

1. Badman MK, Pissios P, Kennedy AR, Koukos G, Flier JS, Maratos-Flier E: Hepatic fibroblast growth factor 21 is regulated by PPARalpha and is a key mediator of hepatic lipid metabolism in ketotic states. Cell Metab 2007, 5:426-437.

2. Inagaki T, Dutchak $P$, Zhao G, Ding $X$, Gautron $L$, Parameswara $V$, Li $Y$, Goetz R, Mohammadi M, Esser V, Elmquist JK, Gerard RD, Burgess SC,
Hammer RE, Mangelsdorf DJ, Kliewer SA, et al: Endocrine regulation of the fasting response by PPARalpha-mediated induction of fibroblast growth factor 21. Cell Metab 2007, 5:415-425.

3. Lundåsen $T$, Hunt MC, Nilsson LM, Sanyal S, Angelin B, Alexson SE, Rudling $M$, et al: PPARalpha is a key regulator of hepatic FGF21. Biochem Biophys Res Commun 2007, 360:437-440.

4. Kharitonenkov A, Shiyanova TL, Koester A, Ford AM, Micanovic R, Galbreath EJ, Sandusky GE, Hammond LJ, Moyers JS, Owens RA, Gromada J, Brozinick JT, Hawkins ED, Wroblewski VJ, Li DS, Mehrbod F, Jaskunas SR, Shanafelt $A B$, et al: FGF-21 as a novel metabolic regulator. J Clin Invest 2005, 115:1627-1635.

5. Coskun T, Bina HA, Schneider MA, Dunbar JD, Hu CC, Chen Y, Moller DE, Kharitonenkov A, et al: Fibroblast growth factor 21 corrects obesity in mice. Endocrinology 2007, 149:6018-6027.

6. Xu J, Lloyd DJ, Hale C, Stanislaus S, Chen M, Sivits G, Vonderfecht S, Hecht R, Li YS, Lindberg RA, Chen JL, Zhang Z, Ko HJ, Kim JK, Véniant MM, et al: Fibroblast growth factor 21 reverses hepatic steatosis, increases energy expenditure, and improves insulin sensitivity in diet-induced obese mice. Diabetes 2009, 58:250-259.

7. Oishi $K$, Uchida D, Ishida N, et al: Circadian expression of FGF21 is induced by PPARalpha activation in the mouse liver. FEBS Lett 2008, 582:3639-3642

8. $Y u$ J, Yu B, Jiang H, Chen D, et al: Conjugated linoleic acid induces hepatic expression of fibroblast growth factor 21 through PPAR-a. $\mathrm{Br} J$ Nutr 2011, 18:1-5.

9. Guthrie JF, Lin BH, Frazao E, et al: Role of food prepared away from home in the American diet, 1977-78 versus 1994-96: changes and consequences. J Nutr Educ Behav 2002, 34:140-150.

10. Huang CJ, Cheung NS, Lu VR, et al: Effects of deteriorated frying oil and dietary protein levels on liver microsomal enzymes in rats. J Am Oil Chem Soc 1988, 65:1796-1803.

11. Eder K, Kirchgessner M, et al: The effect of dietary vitamin E supply and a moderately oxidized oil on activities of hepatic lipogenic enzymes in rats. Lipids 1998, 33:277-283.

12. Eder $\mathrm{K}$, et al: The effects of a dietary oxidized oil on lipid metabolism in rats. Lipids 1999, 34:717-725.

13. Chao PM, Chao CY, Lin FJ, Huang $C$, et al: Oxidized frying oil up-regulates hepatic acyl-CoA oxidase cytochrome P450 4 A1 genes in rats activates PPARalpha. J Nutr 2001, 131:3166-3174.

14. Eder K, Suelzle A, Skufca P, Brandsch C, Hirche F, et al: Effects of dietary thermoxidized fats on expression and activities of hepatic lipogenic enzymes in rats. Lipids 2003, 38:31-38.

15. Chao PM, Huang HL, Liao CH, Huang ST, Huang CJ, et al: A high oxidised frying oil content diet is less adipogenic, but induces glucose intolerance in rodents. Br J Nutr 2007, 98:63-71.

16. Kämmerer I, Ringseis $R$, Eder $K$, et al: Feeding a thermally oxidised fat inhibits atherosclerotic plaque formation in the aortic root of LDL receptor-deficient mice. Br J Nutr 2011, 105:190-199.

17. Chao PM, Hsu SC, Lin FJ, Li YJ, Huang CJ, et al: The up-regulation of hepatic acyl-CoA oxidase and cytochrome P450 4A1 mRNA expression by dietary oxidized frying oil is comparable between male and female rats. Lipids 2004, 39:233-238.

18. Chao PM, Yang MF, Tseng YN, Chang KM, Lu KS, Huang CJ, et al: Peroxisome proliferation in liver of rats fed oxidized frying oil. J Nutr Sci Vitaminol 2005, 51:361-368

19. Sülzle A, Hirche F, Eder $K$, et al: Thermally oxidized dietary fat upregulates the expression of target genes of PPARa in rat liver. J Nutr 2004, 134:1375-1383.

20. Ringseis $R$, Eder $K$ : Regulation of genes involved in lipid metabolism by dietary oxidized fat. Mol Nutr Food Res 2011, 55:109-121.

21. Varady J, Gessner DK, Most E, Eder K, Ringseis R: Dietary moderately oxidized oil activates the Nrf2 signaling pathway in the liver of pigs. Lipids Health Dis (in press).

22. Gesellschaft für Ernährungsphysiologie: Empfehlungen zur Energie und Nährstoffversorgung bei Schweinen Frankfurt, Germany DLG-Verlag; 2006.

23. Keller J, Ringseis R, Koc A, Lukas I, Kluge H, Eder K: Supplementation with $\mathrm{L}$-carnitine downregulates genes of the ubiquitin proteasome system in the skeletal muscle and liver of piglets. Animal 2011, 6:70-78.

24. Luci S, König B, Giemsa B, Huber S, Hause Gl, Kluge H, Stangl, Eder K: Feeding of a deep-fried fat causes PPARalpha activation in the liver of pigs as a non-proliferating species. Br J Nutr 2007, 97:872-882. 
25. Cheon Y, Nara TY, Band MR, Beever JE, Wallig MA, Nakamura MT: Induction of overlapping genes by fasting and a peroxisome proliferator in pigs: evidence of functional PPARalpha in nonproliferating species. Am J Physiol Regul Integr Comp Physiol 2005, 288:1525-1535.

26. Luci S, Giemsa B, Kluge H, Eder K: Clofibrate causes an upregulation of PPARa target genes but does not alter expression of SREBP target genes in liver and adipose tissue of pigs. Am J Physiol Regul Integr Comp Physiol 2007, 293:70-77.

27. Kharitonenkov A, Wroblewski VJ, Koester A, Chen YF, Clutinger CK, Tigno XT, Hansen $B C$, Shanafelt $A B$, Etgen $G$ J: The metabolic state of diabetic monkeys is regulated by fibroblast growth factor-21. Endocrinology 2007, 148:774-781.

28. Winegar DA, Brown PJ, Wilkison WO, Lewis MC, Ott RJ, Tong WQ, Brown HR, Lehmann JM, Kliewer SA, Plunket KD, Way JM, Bodkin NL, Hansen BC: Effects of fenofibrate on lipid parameters in obese rhesus monkeys. J Lipid Res 2001, 42:1543-1551.

29. Chou CJ, Haluzik M, Gregory C, Dietz KR, Vinson C, Gavrilova O, Reitman ML: WY14,643, a peroxisome proliferator-activated receptor alpha (PPARalpha ) agonist, improves hepatic and muscle steatosis and reverses insulin resistance in lipoatrophic A-ZIP/F-1 mice. J Biol Chem 2002, 277:24484-24489

30. Tsuchida A, Yamauchi T, Takekawa S, Hada Y, Ito Y, Maki T, Kadowaki T: Peroxisome proliferator-activated receptor (PPAR)alpha activation increases adiponectin receptors and reduces obesity-related inflammation in adipose tissue: comparison of activation of PPARa, PPAR $\gamma$, and their combination. Diabetes 2005, 54:3358-3370.

31. Eder K, Keller U, Hirche F, Brandsch C: Thermally oxidized dietary fats increase the susceptibility of rat LDL to lipid peroxidation but not their uptake by macrophages. J Nutr 2003, 133:2830-2837.

32. Ammouche A, Rouaki F, Bitam A, Bellal MM: Effect of ingestion of thermally oxidized sunflower oil on the fatty acid composition and antioxidant enzymes of rat liver and brain in development. Ann Nutr Metab 2002, 46:268-275.

33. Koch A, König B, Spielmann J, Leitner A, Stangl Gl, Eder K: Thermally oxidized oil increases the expression of insulin-induced genes and inhibits activation of sterol regulatory element-binding protein- 2 in rat liver. J Nutr 2007, 137:2018-2023.

34. Liao CH, Shaw HM, Chao PM: Impairment of glucose metabolism in mice induced by dietary oxidized frying oil is different from that induced by conjugated linoleic acid. Nutrition 2008, 24:744-752.

35. Ringseis R, Muschick A, Eder K: Dietary oxidized fat prevents ethanolinduced triacylglycerol accumulation and increases expression of PPARa target genes in rat liver. J Nutr 2007, 137:77-83.

36. Eder $K$ : The effect of an oxidized dietary oil on plasma cholesterol and thyroid hormone concentrations in miniature pigs fed a hyperlipidemic diet. J Anim Physiol Anim Nutr 1999, 82:271-281.

37. Eder K, Stangl GI: Plasma thyroxine and cholesterol concentrations of miniature pigs are influenced by thermally oxidized dietary lipids. J Nutr 2000, 130:116-121.

doi:10.1186/1476-511X-11-34

Cite this article as: Varady et al:: Dietary moderately oxidized oil induces expression of fibroblast growth factor 21 in the liver of pigs. Lipids in Health and Disease 2012 11:34.

\section{Submit your next manuscript to BioMed Central and take full advantage of:}

- Convenient online submission

- Thorough peer review

- No space constraints or color figure charges

- Immediate publication on acceptance

- Inclusion in PubMed, CAS, Scopus and Google Scholar

- Research which is freely available for redistribution

Submit your manuscript at www.biomedcentral.com/submit 